\title{
Crafting Sacrality from the tensile life of objects: learning about the material life of prayer beads from a Khaksari Sufi Murshid
}

\author{
Younes Saramifar ${ }^{1}$
}

Published online: 10 November 2017

(C) The Author(s) 2017. This article is an open access publication

\begin{abstract}
Sufi mystical experiences and practices are populated with objects. Objects exist among masters as well as disciples and followers regardless of the meanings and significations that practices impose on them. The life of these objects begins before they are enacted into sociocultural and religious relationships, as they are crafted or traded before they take on the overwhelming semiosis ascribed to them by religiouscultural codes or social networks. This article presents an apprenticeship ethnographic journey in which I follow an Iranian Sufi master and, along with him, the tensile life of Sufi prayer beads, or tasbihs. I address prayer beads as an object prior to their gaining of any religious meaning in the networks of everyday life. Tracing the material life of prayer beads reveals how the "objectness" of the rosary preexists the material practices that give it meaning in the Sufi order. Through the approach of speculative realism I examine what it means to study a religious-object-in-itself. I follow the religiously loaded object and its spiritual emergence by way of object-oriented ontology to forgo the meanings and relationships that shadow the objects.
\end{abstract}

Keywords Object-ness · Object oriented ontology (OOO) - Rosary · Prayer beads . Anthropology of Tariqat $\cdot$ Material Sufism

I have been enchanted by colourful prayer beads and the click-click-click of the beads falling onto each other in my grandfather's hand. The sound also calls to my mind the hands of Sayed Doa, who lived next door to my house when I was growing up and foretold the future through the beads. I was born in Iran, where the tasbih, prayer beads or rosaries, are a constant companion of practicing Shi' as. They are found in various sizes and shapes, and carried in pockets, placed between the folds of prayer rugs, kept next to

Younes Saramifar

y.saramifar@vu.nl

1 Department of Social and Cultural Anthropology, Vrije Universiteit Amsterdam, Amsterdam, Netherlands 
the Quran, fashionably looped around a wrist. I became familiar with these rosaries because I was born in a place where Shi' ism is the predominant faith and shrines are plenty. Every shop in the old part of Isfahan near the shrine and the cemetery sold rosaries along with other religious items. However, by 2007, economic crisis, inflation, and increasing rents forced most of those shopkeepers to either sell their stores or change their business to something more profitable. The only shop that remained of this traditional trade was that of Mulla Habib, who was firmly dedicated to his trade. He handcrafted the rosaries, carving the beads from a variety of materials. He turned enough profit to maintain his store near the shrine and served only select clientele.

In this article, I explore the life of prayer beads as expressed in the ideas and notions of the Khaksari Sufi order, of which Mulla Habib held the title of murshid kuchak (lesser master) in Isfahan until he passed away in early 2012. He carved the beads and crafted the tasbihs to his last day, and under his guidance I traced the object-ness and materiality of the tasbihs. I became his apprentice in order to conduct an ethnography of the tasbihs and explore "how religion happens materially" (Meyer, Morgan, Paine, \& Plate 2011: 207-211). My ethnography of the last year in the life of this Sufi murshid is what Tim Ingold (see Jones, 2003) calls apprenticeship ethnography, and the practice redefines and develops the traditional anthropological method of participant observation into an act of collaboration and learning. I remained his apprentice from 2010 until early 2012. I concentrate here on three months that I was allowed to stay at his home in Isfahan while the Sufi murshid was ailing. Throughout this article, I have attempted to maintain the ontological authority of Mulla Habib in my writing style by discussing theory alongside tales and ethnography so as to not weigh down his own ways of seeing and addressing the world with the weight of jargon and abstraction. ${ }^{1}$ Therefore, the tales of apprenticeship are in the form of a narrative that corresponds to the theoretical framework instead of trying to mix theory with description.

My apprenticeship was a new development for me, but my familiarity was with the order was old. I was introduced to the Khaksari order through the maternal side of my family, who have been close to the order since the early years of its founding in central Iran. Because the context of my inquiry remains close to me and my upbringing, and given my proximity to the question at hand, as well as factors beyond my control in this research, such as an affection for the larger principles of Sufism, my inquiry is rooted in what Haraway (1988) calls situated knowledge. However, I don't claim to have the role of "privileged stranger" (Aamodt 1983); I had left behind any allure for the Khaksari Sufi order long before apprenticing myself or confirming a covenant with any murshid. Despite this situated knowledge, I was challenged to discard my notions of the prayer beads and their meaning when I became familiar with a different reality while conducting participant observation in the workshop of the Sufi murshid. I always had assumed that the tasbihs were tools in the service of believers and prayers, but under the guidance of the Sufi murshid, I was tasked with comprehending the sovereign presence of the tasbihs and the raw materials of the beads.

\footnotetext{
${ }^{1}$ The ontological authority of correspondents refers to assigning the authority of telling to the people who share with the ethnographer how the world is seen and how the components of that world are placed in their organic perceptions. To assign the authority is not to maintain the right over the ethnographic tales told but to surrender to the coherence believed in by the people who welcome and permit us ethnographers entry to their world.
} 
My relationship with the Sufi murshid did not depend on my background: I was never initiated into the order, and he did not have a personal relationship with me despite the fact that I had known of him since my childhood. In early 2008 I was associated with an advocacy campaign that helped minority groups in the cities of Isfahan, Semnan, Arak, and Yazd. The campaign advised religious minorities and Sufi orders that practiced Shi'ism in a manner different from what the Iranian state declares to be the true practice of Islam. Therefore, my close interactions with the Khaksari order made it possible to establish a relationship with the Sufi murshid and finally become his apprentice. My encounters with Mulla Habib describe the tale of an object believed to be religiously and spiritually loaded object by the Khaksari dervishes, also known as Gonabadies among Iranians who follow and pay tribute to this order.

Under the guidance of Mulla Habib, I learned the ways of objects and how materials remain independent of materiality. I share my observations to speak of the constant yoyo and discrete movements of materials toward materiality by considering the materials prior to the saturation with meanings rather than through them. I account for how the object-ness of materials and their raw existence were acknowledged before the emergence of materiality through the craftsmanship of Mulla Habib and mystical practices. I do not dismiss the representationality or material culture that evolves around the prayer beads. I emphasize what happens before emergence and imposition of the meaning to reveal the tension that encompasses the contribution of material-in-itself to materiality and the configuration of meanings. In sum, I use the tensile of life of prayer beads as an example in service of my theoretical framework to call for an anthropology of religion that includes aspects beyond transcendence, worship, rituals, and rites in the spheres of religiosity and religious practices.

My framework is inspired by Graham Harman's (2013) object-oriented ontology (OOO) and speculative realism. First, I discuss my departure from the phenomenology of objects and Latourian relationality in light of speculative realism. The following section offers a critique of limiting the objects to the intentionality of human minds and of restraining any object in the relations formed in correspondence with social imaginaries and cultural functions. In addition, the relationality approach engages with finding the actant side of each object, such that it loses sight of the object's existence before the formation of relationships and networks. Second, in my approach to the life of various rosaries and prayer beads, and their usage among dervishes, I explore the joys and poetics of understanding an object before the shadow of meanings are ascribed to them in the everyday life and practices of the Sufi murshid. Thus, I follow the joys and poetics to trace what is prior to the materiality and the saturation of the objects with meaning to argue that an object is something that has happened already. This is in disagreement with David Morgan (2011: 141), who suggests that "we might say that a thing is an object waiting to happen." I put forward the tales of the tasbihs to suggest that it is the human in contact with the object that is yet to happen or is "waiting to happen."

\section{Trailing objects without their shadows}

Meyer and her colleagues discuss the "sensory characteristic of religious practices" in their portrayal of material religion (Meyer et al. 2011: 5). They propose that the question of how religion happens materially moves beyond the rudimentary question 
of what material signifies or means in the realm of religion and religiosity. They propose that the materiality of religious objects is firmly embedded in religions; thus, "a materialized study of religion begins with the assumption that things, their use, their evaluation, and their appeal are not something added to a religion, but rather, inextricable from it" (Meyer et al. 2011: 207-211). David Morgan furthers the inextricability of material: "If culture is full range of thoughts, feelings, objects, words, and practices that human beings use to construct and maintain. .. [then] material culture is any aspect of that world-making activity that happens in material form" $(2008,228)$. These suggestions are all well-rounded ideas that make perfect sense to most social scientists. However, why is the material addressed only after human signification has already interfered with it? Why is the autonomy of material, regardless of its relationship to humans, ignored? Meyer and her colleagues don't link the inextricability of the materiality of an object with the object's own sovereign existence. It seems that, for them, an object must come into contact with the affairs of humans, such as religion, to be considered worthy of existence.

Tim Ingold critiques the overemphasis on an object's materiality in debates taking place in forensic anthropology, archaeology, architecture, and human geography. He proposes that an object's materiality be traced through the circulations and processes that it goes through, emphasizing the "focus. .. on the artifactual domain at the expense of living organisms" (Ingold 2012, 428). Furthermore, he writes that "the prevailing emphasis on materiality obstructs our understanding of the field of forces and circulations of materials" $(2012,428)$. In other words, he tries to bring our attention to the "ontogenesis" of materials, which he defines as "the interactive convocation of exiting entities" (Ingold 2012: 431, 437) that delivers the objects and configures their materiality in relationship with surrounding elements. He limits the very existence (ontic) of the objects into a web of relations and responsive movements (genesis) at the expense of their life before interactions and relations.

There has been a growing body of work on processes of materiality and object emergence that is contributing to anthropology (see; Brown 2001; Dubois 2003). Those engaged specifically with anthropology at large have made important queries into the ontology of objects (see Pinney 2004; Naguib 2015; Meyer 2008). These works have been substantial enough to pique the curiosity of philosophers such as Harman (2014a, (b), Manuel DeLanda (2015), and Tristan Garcia (2014), such that they speak about the objects in reaction to these studies as well as inspiration from them. For instance, Harman (2009) speaks of history, art, architecture, and anthropology to draw examples and substance for his description of an object-in-itself, and he states the need for accounting for materials before their materiality in his conversations with Bruno Latour, the celebrated French anthropologist, in opposition to the notion of relationality. DeLanda (2015) draws from Clifford Geertz to explain his assemblage system theory and the trajectory from materials to materiality in the emergence of signification. Consequently, these philosophers' arguments can easily be traced to the ontological turn in anthropology and works of anthropologists such as Martin Holbraad, Amiria Henare, and Sari Wastell (2007). In the end, I don't accept Ingold's concern for the overemphasis on materiality and his suggestion to pay attention to object relationality.

Eisenlohr (2009) and Meyer both have noticed the "the propensity of media to 'disappear' in the process of mediation" (Meyer 2011: 62). They note the disappearance of an object and its material existence by acknowledging and have acknowledged 
how an object that is understood and treated as a medium, such as an image, "renders [the unseen] present to the observer" (Meyer 2011: 62, emphasis removed). Such an approach is crafted through an exploration of the circulation of objects among people, their formal emergence (production), and "how they address beholders by triggering particular sensations" (Meyer 2008: 127). For instance, Meyer refers to the Catholic icons that "appear as an embodiment of a sacred presence that can be experienced by contemplative gaze, prayer, or a kiss" (2008: 127). But she does not actually invoke the material religion to explain how objects sustain that embodiment either within their own object-ness or when the embodiment fades away from them; nor does she explore how the material-in-itself contributes to triggering the sensations. In my example, Mulla Habib was meticulous, bordering on obsessive, in choosing the materials for carving beads. In addition, he crafted beads only by hand to remain faithful to the delicacy of the materials. He would break his rule only when drilling holes in the center of the beads with an electric drill, which he justified by explaining how the size of the holes and the thickness of the string determine how easily a devotee can use a tasbih without any distraction while calling the name of God. A tasbih that is carved with care and precision forms a mutually corresponding link with devotees and allows for the emergence of materiality. Hence, it is not only the materiality that requires attention because it is the scenario that humans happen to play in it. We must account for how the material-in-itself contributes to the materiality that we speak of in material religion.

I note the object-ness and presence of an object regardless of the sacrality or materiality that the object embodies. I call this surplus of objects that affect the trajectory of an object's embodying the sacred presence object-ness or material prior to materiality. The object is and remains an existing unit before the meaning ascribed to and gathered around it. The object sustains a surplus beyond the fabricated networks of the imaginaries and realities of humans and their religious practices. It is necessary to remember a poster, a figurine, or a piece of fabric sustains its material texture and craftsmanship despite being removed for whatever reason from the network of sacrality. Consideration of the ontic modes alongside ontogenesis helps us trace how the religiously and spiritually loaded objects interact with the faithful as well as why the objects are capable of sustaining sacrality in themselves. This is the first step toward understanding the object in itself.

I use the terms thing, object, artifact, and material interchangeably, and I see no use in the rhetoric and theoretical debates to distinguish one term from another. For instance, Tristan Garcia devotes two hundred pages of his treatise on things to distinguish among things, objects, materials, and forms. However, he concludes the discussions and debates are not rich enough because "the formal system is poor. .. while the objective system [i.e., the life of objects on their own] is rich in content. .. and multiple in every direction, ad infinitum" (Garcia 2014: 152).

I am wary of the debate over "incessant interaction with endlessly varied artefacts" (Schiffer \& Miller 1999: 2) or the "objectness of things to the material flow" (Ingold 2012: 431) and the notion that "materials. .. are substance-in-becoming" (Barad 2003: 822). I am unsure of how such arguments add to the establishment of an anthropology of objects and material religion in general. These debates do not include the objects prior to the emergence of meaning or modes of materiality. They mold the elusive life of objects into an accessible reality without addressing the existence of objects beyond the questioning of the beholder. With this in mind, I refer to the tasbih as an object to 
convey both its tactile and its intactile modes of existence. The term implies both its object-ness and the emotional response to the object, and the semantic context allows for readers to infer the distinction.

To speak of object-ness, surplus, and material prior to materiality and signification, I follow the approach of speculative realism and its efforts to collapse subject versus object and the human versus nonhuman divide. Graham Harman (2012), whose objectoriented ontology and speculative realism is more relevant to social sciences, highlights the tensile life of objects. He traces the tension that comes prior and after the emergence of meaning and signification in the writings of Sir Arthur Eddington, a British astrophysicist who in 1919 confirmed Einstein's general theory of relativity. Harman narrates how Eddington stated that there were duplicates of every object about him because he distinguished between the table as it appears in the everyday encounters in which it is experienced and the way physics describes it through quantifying its components and chemical compositions. Harman uses this contrast to propose a third table, bringing our attention to the object in itself and so developing his object-oriented ontology (OOO). In what follows, I use the notions of Mulla Habib to further introduce $\mathrm{OOO}$ into debates on material religion.

The stories and conversations I share here avoids "undermining" or "overmining" (Harman 2011) the tasbih, as such an approach includes the surplus that remains in materials while also tracing the intricate process of emergence. For instance, Janet Hoskins overmines objects in her discussion of gendering objects; she situates objects in relation "to remembering them, and the power of objects to embody memory" (2007: 112). They are "overmined" by virtue of their manifestation to the human mind, consciousness, and intentionality. However, I suggest that objects are singularities that disguise a multitude of traits and "will not [be] reduced to the glory of others' [mind or consciousness]" (Harman 2011: 7). A tasbih is not merely the sedimentations of the sacred moving between the faithful's fingers; rather, it is a unit of its own reality, regardless of the faithful. It holds a mode of existence apart from the formal construct that speaks of its chemical composition and independent of the material culture that speaks of its representational qualities. Therefore, the task ahead is to find the tale of objects by questioning not what "is in it, nor that in which it is, but rather the difference between these two extremes" (Harman 2014b: xxiv).

There is another side to the tension operating between the two extremes that Harman mentions. Any object (and by association, any concept) can be undermined by assuming it to be a "mere surface of effect of some deeper force" (Harman 2011: 6). For instance, an insistence on returning to the materials prior to materiality and accounting for the object-ness could bring about the risk of scientism and the reduction of everything to its state of physical being without considering the becoming. Therefore, Harman (2011) suggests that Eddington undermined the tables into their scientific existence. Harman refuses to see objects with regard to their external and internal environments and invites us to see a "real. .. [object that is] in fact. .. lying between these two others" (2011: 7). I don't go as far as Harman to find the "real" tasbih. However, I propose that we consider the object-ness that corresponds and contributes to materiality and material practices of religion by considering the inbetweenness and co-constitutions in material practices to get closer to how religion happens materially. 
The in-between where material or object "emerge[s] as something distinct from its own components and also withdraws behind all its external effects" (Harman 2012: 10, emphasis original). For instance, Mulla Habib insisted that the scent emitted from a particular clay tasbih was because the beads were made from a clay sourced from blessed land. He asked me to exhale on his tasbih-e-turbat, an old tasbih made from clay and soil. It smelled of adobe mixed with rosewater and musk, and the scent of petrichor gave a pleasant smell to the clay, but it held a rich and blood-saturated history too. He told me that the scent is because the clay is from turbat (soil) of a qatlegah (place of killing) where the blood of the innocent was shed. He referred to the story of Karbala, the seventh-century battle in which Muhammad's grandson Hussein was brutally beheaded. ${ }^{2}$ The soil of qatlegah has been a rare, sacred relic from Karbala ever since Saddam Hussein covered the ground where the beheading took place with stones. So the tasbih-e-turbat is not the clay, or the rosewater mixed with the soil or the petrichor; it is not something with vojoud (presence) carrying the memory of innocent blood. Rather, it is that elusive quality that holds both emergence and withdrawal together. We become aware of them only by returning to the turbat prior to its representations or to how petrichor contributes to that representation.

Returning to the turbat prior to its representation and finding how its object-ness contributes to the emergence of its religious materiality can be traced in Shi'i practices in addition to the Khaksari order. For instance, Shi'i devotees use a mohr (prayer stone) in their daily prayers. The mohr is made of clay similar to the one Mulla Habib used to craft his tasbih, which offers a soft, smooth, absorbent surface with which to touch one's forehead while praying. The clay represents dust, and touching it to the forehead symbolizes humility in front of Allah. However, the material qualities of the clay demand an inquiry into what the clay of a mohr contributes to the materiality that appears between devotee and object. Otherwise, a hard rock, a piece of marble, rubble, or even a leaf, can be used as a praying stone according Shi'i jurisprudence.

Harman attempts to add a new spectrum of thoughts in addressing materiality by highlighting the surplus that resists overmining and undermining. The surplus, that something-in-between or elusive quality, may well remind us of Latourian relationality, which addresses these various aspects through networks of relations among each and every element. Latour's (1993) approach proposes a bridge between objects and humans, removing the nature-culture divide and emphasizing how objects and humans are located in a network without the normative divide of nature and culture. The distributed relationality across this network is as ontologically indiscernible as nature and culture, which are entangled ontologically. The scent of clay, the history that speaks of innocent blood, and emotions provoked in reaction to that history are all constitutive elements that deliver and correspond to one another in the networks that configure a tasbih's mystical presence. The indiscernibility that informs the materiality of these constitutive elements shows how they correspond with one another through their modes of affecting each other while also maintaining their autonomy and existence. However, Latourian relationality reduces the indiscernibility and mutual correspondence to an entanglement that disregards what comes prior to network and relationship. The entanglement is certainly welcome; however, Latour overmines objects in his network

\footnotetext{
${ }^{2}$ The Battle of Karbala is important to Shi'i Muslims, as the story signifies the sacrifice offered by their Third Imam, much like Catholics who believe in the sacrificial blood of Jesus.
} 
(Harman 2009). All constitutive elements of the network are occupied in relation to another. The |Latourian network explains the proposition by Meyer and her colleagues (2011) that religion happens materially. However, it does not offer an account of objectness or how that object-ness contributes to the tasbihs into the companions of ritual and prayer.

Relationality leaves no occasion for the sovereign existence of elements apart from their relationship with other elements in the network. It seems that things in themselves are simply forgotten, or when they are remembered, then it is only "without an unexpressed surplus in the heart of any entity" (Harman 2014b: 42). The other difficulty that arises from Latourian relationality is its lesser attention to the details of relationships. The network of relationality, that both human and nonhuman are placed in, does not distinguish a relationship between two nonhuman entities from one with one human entity and a nonhuman one (Harman 2014a). For instance, the object-ness of the clay in the prayer beads or plastic would implicitly have the same relationship for the faithful, such that how each different kind of bead contributes to what Meyer and Morgan call happening materially would be missed. Thus, Latourian relationality can be a departure point, rather than a holding area, for the study of objects in the realm of religion and religiosity.

\section{Tracing the beads of tasbihs}

I don't remember what originally brought me to Mulla Habib's shop for the first time when I was young. I wonder if it was the tantalizing and colourful tasbihs that attracted me, or the tranquil smiles of the old man who sold them. The shop was never empty, with a continuous stream of pilgrims who visited the nearby shrine as well as dervishes and disciples who visited him. Mulla Habib was a murshid kuchak, a lesser master assigned by a murshid (master) to guide disciples of the Khaksari Sufi order in the city of Isfahan. When I lingered in his shop as a teenager he always smiled and allowed me to wander happily among the prayer beads and would answer my curiosities.

He constantly reminded me that there is a world hidden in ashyaâ (objects), which call on us for them to be turned and sensed in the hand of believers. The tasbihs turn the wheel of time while believers recite zikrs (chants). Mulla Habib gifted me a tasbih when I turned fifteen, the age at which a male Muslim is obligated to pray and observe rituals. He stressed that the name tasbih was not given randomly to the prayer beads without much explanation, to encourage me to consider the object seriously and perhaps think about his coded wisdom. Mulla Habib, like most murshids, spoke in short, succinct phrases that the disciples would try to reflect on them while chanting or practicing sokut (a form of Sufi mediation that requires keeping silence and thinking about God but not chanting the name of God).

He spoke of the tasbihs to his disciples with an imperative tone but in a convoluted manner. Interpreting, meditating on, and pondering the wisdom he shared would generate an aura of sacrality when the tasbih was touched and prayed with. That wisdom would encourage disciples to treat the tasbih as a way to unite a dervish with all who turned zulal (translucent) while they called for the Almighty before him or her. The aura of sacrality and generated materiality determined the practices of dervishes. They should not disrespect their tasbihs by throwing them aside or folding them around 
their wrists in manner of some youth who find it fashionable or they would refer to their tasbihs in an eloquent manner. Mulla Habib always seemed conscious of using the term Ashyaâ, the Arabic plural for sheiâ, when he referred to the materials associated with his craft and making the prayer beads. He tried to remain respectful of an entity by using the term Sheia because most Iranian of religious bent use Arabic words to add more gravitas to their articulations and references. In referring to some objects, Mulla Habib found term sheia more elegant than colloquial slang such as chiz.

Mulla Habib spoke of objects and inanimate life in a manner that made me initially wonder about his mental faculties and how seriously I should take his comments in my ethnographic notes. This impression of him, though, was because he was unhappy and melancholy, having lost his shop and shifted everything to his home. His shop had been plundered, and he was attacked because President Mahmoud Ahmadinejad had made life near impossible for religious minorities and those who practiced Shi'ism differently. Starting in 2007 Ahmadinejad targeted dervishes and Sufi orders that were popular among Iran's ethnic minorities, such as Kurds, Baloch, and Turkmen, accusing them of deviant religious practices. The regime began by bulldozing the Khaneqah, a Sufi house of worship, which led to brutal attacks against the Sufis' peaceful protest to demand their rights and compensation by the state. The brutality snowballed in the provinces, leading opportunists to target murshids like Mulla Habib and occupy their shops or lands.

Mulla Habib was troubled by the events, but I realized during my apprenticeship that my initial assumptions were naïve and that the murshid experienced life through different realities. Yusuf, a young disciple in the service of the murshid, provided me with insights and stories to help me realize that Mulla Habib spoke of the inanimate life differently than most others did. Yusuf was an experienced geologist who was trying to confirm divine and sublime experiences through scientific reason. For him, the life of material was close to Eddington's scientism and undermined objects. Yusuf was aware my disbelief of sacrality; he intervened with scientific input to bring my straying soul back to the path. He insisted that his understanding of the sacred was supported by science.

Mulla Habib crafted the tasbihs by stringing the beads together, side by side, on a strong and preferably green thread. Once the beads are strung, the two ends of the thread are passed through a bead of similar quality, but it is usually larger and cone shaped. This larger bead is called the Caliph, Shaykh, or Akhund. To provoke him and make him to talk few more sentences, I mentioned to him that Greeks call the large bead of their Kimboloi (rosary) paps - the priest (Edwards 2004, 94). He frowned and said "I need to teach you the ways of the soul. What they have has no soul. It's just like the plastic rosary that you get all around the market. Our tasbihs talk to you if you listen." I adamantly teased him by asking how can the tasbih and a material-being precede the devotee who uses the tasbih. He responded that the materials would exist regardless of the hand of the devotee, that they are entrusted to a devotee under the gaze of God while both journey toward grace and arrive at an intersection. He reminded me the story of Junayd Baghdadi, the eighth-century Sufi who refused to give up his tasbih. To those who scorned his tasbih and called him a heretic Junayd declared, "I will not abandon it as it has brought me to the God" (translation from Knysh 2007: 72).

Mulla Habib patiently examined each bead and counted ninety-nine for each tasbih. Then, he would run a green thread through thirty-three of them before adding an adask, 
a very small bead that marks a division of the tasbih into three. He mentioned the advice of the Prophet Muhammad to his daughter while weaving a crown for the end of the tasbih with a copper wire to tie the endings of the thread together: Fatimah, the daughter of Muhammad, was advised to call on Allah while repeating his attributes thirty-three times in three sets after the prayers. Therefore, she would call on Allah ninety-nine times in total. Again, I reminded Mulla Habib about the Greeks and their trinitarian komboloi, with thirty-three knots correlating to the reputed age of the death of Christ. He was amused: "Allah has his own secrets and these beads tell them silently."

He held a beautiful red tasbih in the sunlight: "Look how forty-nine beads stand side by sides and one bead stands in between. Do you think the beads would stand so gracefully if they were not odd number in total?" I smiled in acknowledgment, and he added: "They reflect Allah in their gestures. He is one, an odd number, and they come together in an odd number." I debated with him to find out how the aesthetic presence makes the beads divine and to find out where he places his intention while crafting the tasbihs. My attempt disappointed him, though, and he felt misunderstood. He stressed mysterious and unarticulated qualities of life in explaining the materiality that evolved in his craft. I later learned that Mulla Habib's mysterious ways did not imply divine intervention, but he believed a crafted object emerged at peripheries of the divine. He saw the beads next to each other as a gathering of small entities that together produce a totality. That totality was the tasbih and held sacrality, but the beads remained merely well-crafted objects with specific object-ness.

Mulla Habib was kind but determined to teach me the life of the tasbih and entangle my imagination up in it. He drew a tasbih-e-turbat, the old tasbih made from the clay and soil of Karbala, where Muhammad's grandson had shed his blood, from his pocket and handed it to me. He asked me firmly to exhale on it, then smell it. The tasbih again smelled like adobe mixed with the rose water and dark musk fragrance. He snapped at me with an unusual impatient tone and asked if were possible for any other soil to smell that way. His passionate tone reflected the story of Karbala.

He suggested that tasbih-e-turbat would call on Allah without any attempt from devotees to chant; the beads just had to be held in one's hand. Holding and carrying the turbat would bring blessings and assist devotees in their struggle against the material life, according to Mulla Habib. I challenged him by asking how a material object could assist a believer in his or her material life. He rephrased materiality and effect of materials by recalling how prayer beads emit vojoud (presence), which binds itself to the soul of a believer. He realized my hesitation and asked me to gather soil from his backyard. He then brought some rosewater and added it to some clay and instructed me in how to make the clay beads. They did not smell pleasant. Mulla Habib seemed triumphant.

Yusuf intervened and explained the object-ness of the clay beads without any reference to divine or sacred narratives. He explained that the smell of the clay from the backyard would be different from turbat because the soil has much more nitrogen, given the plants and trees in the garden, whereas the soil of Karbala was not cultivated. Thus, it smells of petrichor since it is from arid lands. He added somewhat sarcastically, "This is the same smell you sense after the rain." Mulla Habib turned red while listening to Yusuf. He looked at us and called me a moron for doubting everything and denounced Yusef as a mere scientist. Yusuf and I followed him and sat by the door 
of the room he called his tasbih-khaneh, where he prayed, crafted tasbihs, and stored the valuable beads. He suddenly asked us to just listen quietly, sense the worship of the tasbihs while he turned his own tasbih in hand. I listen as I felt the cold autumn breeze blowing through his room, moving the colourful prayer beads hanging on the walls. The silence and tranquillity among us was so overwhelming that I could not bring myself to ask if he meant the click-click-click of his own tasbih or the dance of the breeze and beads in the room.

A few days later, I found a light blue tasbih by the door while walking in Mulla Habib's house. He glared at me while I played with it. He told me sharply to throw away that cheap Chinese "piece of shit." 3 It was the first time I ever heard Mulla Habib use profanity. He refused to sell or even touch China-made tasbihs, and Chinese-made religious products dominate the market in Iran. However, there is growing resistance among both mystically and conservatively inclined believers against Chinese-made religious objects. China has recognized the lucrative business of pilgrims and religious items in Iran, and its large manufacturing capability has crippled Iranian tasbih craftsmen, and even larger manufacturers. The inexpensive and cheaply made Chinese tasbihs have taken over the Iranian market for religiously loaded objects. Chinese manufacturers produce and supply believers with prayer rugs inscribed with Quranic verses, glow-in-the-dark tasbihs - which strangely look similar to Chinese glowing anal beads - Shi'i prayer books, and even skullcaps and turbans for Shi'i clergy. The beads-in-themselves gathered in a plastic tasbih are no different from, say, the beads used in Mardi Gras parade in New Orleans or sex accessories. A simple Internet search turns up Chinese manufacturers who produce the beads for a variety of purposes. The difference between the beads of the tasbih and any other kind is the tasbih's immersion in a specific mode of materiality and signification.

I threw away the tasbih and asked for his advice on which of the beads would be suitable for me to thread myself. He suggested that zaytuni (tasbih made of olive pits) would be a powerful tasbih for me, as they would require lesser maintenance for someone who does not observe the rituals. I was amused by his suggestion and asked where it came from. He recited verses of the Quran in which Allah confirmed his oath by swearing to olives. ${ }^{4}$ Mulla Habib explained, "They confine the breath of our creator; they resemble the unbreakable oath and the eternal promise of Allah. You cannot break them even with a hammer. They remain smooth and clear." Yusuf then pointed that the pits become smooth only after hours of gentle sanding and polishing them with olive oil. He told Mulla Habib in order to stress object-ness has no link with the divine. Mulla Habib retorted bitterly that all objects are crafted and delivered into their life, and they allow us to do so in a manner suited to them. He particularly pointed out that the pits should not be polished with any oil other than olive oil; otherwise, they would lose their lustre and serene surface. Interestingly, he articulated the loss of lustre by assigning an agency to them, saying that the object would "turn away" or "play hide-and-seek" with the craftsman. This was the first time Yusuf agreed with Mulla Habib, and he mentioned that the beads would "go crazy" if treated with any other oil. I learnt this the hard way when I tried to craft my own tasbih with the olive pits. It seemed difficult

\footnotetext{
${ }^{3}$ This is not to say that he had difficulty with all objects made in China, as some of his carving tools were made in China.

4 "By the fig, by the Olive," chapter 95, verse 1, surat I-tin (The fig).
} 
to point to when Mulla Habib separated the object-ness and the surplus of an object from its sacred presence. His poetic manner of talking about the tasbih revealed an overlap between the ontic modes and the ontogenesis of his craft.

It was intriguing to see how the murshid and his disciple communicated with the world of the object. I came to realize that their approach was not the same for other inanimate objects. They did not have the same respect for a cooking pot or spoon, or even for other religious items, such as images, books, and prayer rugs. The tasbihs who were companions of their prayers, as well as their trade craft, were respected and were treated according to the manner that tasbihs exposed their life to the murshid and his disciple. Under the instructions of Mulla Habib, while I crafted the zaytuni for myself, the life of objects became tangible to me. I experienced the poetry that emerges from the interaction and relationship that Mulla Habib and the beads co-create. The tactile intricacies of the olive pits, the contrasting streaks that form an eclectic pattern in the polished pits, the cooperation of the pits with the olive oil and not any other herbal extract, as well as the endorsement of Allah - all generate a life of the tasbih crafted from olive pits. The life of the object was not dependent on Mulla Habib's perception, and it would sustain itself even if he would cease his relationship with it. The pits would sustain their object-ness regardless of the poetic relationship that humans might form with them. It was the object-ness and being-material in certain form, mode, and composition that contributed to the materiality of the tasbih. In other words, the olive pits had happened already, but they moved, and their discrete movements and ways of being contributed to how others - humans - accompany them in the journey of materiality and becoming-a-tasbih.

The journey along with objects and their object-ness is a way to realize the oscillations and fluidity required in the anthropology of material religion. The journey of Shah Maqsoud tasbih is another story that not only reveals Latour's relationality but also highlights its shortcomings via speculative realism. I asked Mulla Habib about Shah Maqsoud tasbih, the most expensive tasbih after those made from Iranian turquoise, which only ten or fifteen craftsmen in Iran make. Shah Maqsoud is crafted from the semiprecious stone olivine (or gem-quality peridot) mined in Afghanistan. The mine is located near the shrine of the old Sufi master Shah Maqsoud Oveisy, who is associated with one of the Prophet's disciples. There are various myths and legends associated with olivine; for instance, it is called a Pazahri (antidote) tasbih because its powder can cure snakebite or mosquito bites. Yusuf was quick to correct the legend. He said that olivine is rich in magnesium, an anti-inflammatory agent for open wounds.

Shah Maqsoud is particularly expensive because of its fascinating beads. They take on lighter shades the more they are touched and rubbed while chanting. Some of the yellowish beads become completely transparent after decades of usage and prayers. Mulla Habib used this specific quality to explain that a Shah Maqsoud tasbih becomes a desired object because the beads are polished along with the heart of the faithful who prays with them. The object and its owner reach together for Allah and the unseen. The visible and tangible changes in the shade and colour of the beads is understood as the beads acting to align the faithful to the environment. According to Mulla Habib, "The beads with their authentic and truth-seeking quality call on malaks [angels] and the hand of unseen." The faithful are polluted and affected by years of sin, and those sins turn the stone opaque. However, the stone and the faithful form a bound through the link of ownership and prayers when they are crafted to a tasbih to compensate for those sins. Mulla Habib 
stressed that Shah Maqsoud beads have the upper hand in relationship with devotees because their nature remains innocent and they already have accessed the unseen.

The poetic rhetoric of Mulla Habib was enchanting, but Yusuf's dismissive attitude made me curious about his opinion. According to Yusuf, magnesium and nesosilicate compounds in olivine interact with ammonia in the perspiration of a person's palm while the beads are run through the fingers, and so the beads become a lighter shade. He also suggested - but he was not sure of this hypothesis - that chloride in sweat and iron in the mineral react together with the heat generated from the bodily contact with the beads. Certainly, Mulla Habib was not convinced by those propositions and adamantly wanted to prove Yusuf wrong. He mentioned that Chinese have bought mining concessions in Shah Maqsoud and produce a cheaper variety of the olivine tasbihs. The Chinese Shah Maqsoud is priced around fifty to seventy dollars, whereas one from Afghanistan easily goes for fifteen hundred dollars, but the Chinese one emits no charm.

Mulla Habib brought a Chinese-made Shah Maqsoud to compare with an Afghanistan-made one. He asked me to touch the Chinese one, run it between my fingers, then repeat with the Afghan one. Mulla Habib described the sensation of the Afghan beads he touched with endearing (feminine) adjectives like latif (tender), narm (soft), and panbeh-yee (delicate). The Chinese beads, he said, felt "like a hard stone." It was first time that he spoke of the beads with such a gentle and gendered languageFarsi in general is not marked by gender, and gender must be explicitly stated, even in the presence of pronouns. However, Mulla Habib's tone was more than telling, and he used attributes frequently found in Farsi romantic poetry.

I listened to him with attention. The surface of the Afghan beads seemed slightly abrasive and the Chinese ones, thoroughly smooth. Mulla Habib happily agreed: the faithful would sense the abrasive surface more, and so the tasbih would remain more "connected" to the faithful. The abrasive sensation was not understood and felt not like its everyday definition but the opposite meanings emerged in the realm of materiality co-created by Mulla Habib and the beads. Material semiosis (Law 2009) emerged not on behalf of Mulla Habib but in collaboration and via the contributions of the materials to the meaning-making process and the mystical semiosis assumed by the murshid. The experience of touch, in connection with how the stone was sensed, was configured by elements more than by the relationship of skin and stone. The beads themselves are an actant in the interaction as much as are God, the mines, the trade, and the one ready to pay the cost and unlock the mysteries of the unseen. The Shah Maqsoud prayer beads are in a Latourian network while also being the chemical compositions that Yusuf talks about and the mystical configuration that assists the faithful along the path, according to the Sufi master. But, none of those features is accessed simultaneously. Some of the features are held back every time someone or something interacts with the beads. For instance, a believer interacts merely with the apparent material and mystical features of the beads during their prayers when they become more transparent and supposedly attract hands of the unseen, but the chemical compositions that interacts with sweat or if it is made in China or Afghanistan are not accounted for in the relationship. Another example is found in the production and crafting of the beads. In Afghanistan, craftsmen soak the beads in castor oil, then polish and shape them on an aluminum oxide grinding wheel. However, none of those contacts relates to the mystical features of the stone. The production process and how one chemical composition comes in contact with another withholds the relationship formed between the believer and the stone that is 
carved into the beads. Similarly, Afghan craftsmen who recite the attributes of God while they work, to request prosperity or add creativity to the process withhold that relationship between the believer and the beads. Their action has nothing to do the mystical qualities that the believer will try to invoke from the beads.

There is always something held back; objects resist complete recognition and revelation. Hence, I stress the object-ness of each object, which reveals the speculative reality of objects that propose the accessed and inaccessed realities of objects without forgetting that they hide from us and sustain their sovereignty regardless of us. The sovereignty emerges in various levels and intensity. For example, Yusuf never carried a tasbih because he did not like their weight in his pocket. However, he explained that he did not like anything in the pockets of his pants, be it coins or a mobile phone, when I said he could carry a small wooden tasbih if he were hesitant like his murshid about the light plastic tasbih. His refusal spoke of the interaction between the tasbih and the light fabric of Yusuf's pants, both of which correspond to each other's existence. The mutual correspondence and the interaction of different forms of object-ness are the "accidental feature" (Harman 2011: 250) of the beads, their weight, which brings about what Yusuf viewed as inconvenient. However, I mistakenly assumed that the scientism of his religious approach makes him to avoid tasbihs.

I mention this anecdote to highlight how object-ness remains independent of meanings, materiality, and relationality. Relationality does not account for the change in objects because it neglects to focus how the change in an object influences the change in the relationships. For example, the weight of the beads can be reduced by carving them smaller or increasing size of the hole that the thread passes through. However, these alterations change the object-ness of the tasbih overall for the faithful. The beads would not move with the necessary ease if the thread or the holes change, and the experience of the faithful who uses the tasbih would change accordingly. However, Latourian relationality does not account for changes because it ignores the material prior to materiality. The network of relationships is not as stable as suggested by Latour (2005), however, an anthropology inspired by object-oriented ontology which accounts for accidental features and object-ness of the objects expands our approaches toward a speculative aspects of realties that neither transcends to representationality nor remains limited into materiality. It is in the tension, the yoyo, the oscillation, and the discrete movements among material, materiality, and representation that we should understand to be able answer how the tensile life of objects affects immaterial and affective religious experiences.

\section{The tensile life of objects}

I began the tale of my apprenticeship under the guidance of the murshid Mulla Habib by stepping away from those who propose theories that undermine or overmine objects. I have stressed that objects cannot be reduced to their representational qualities, and they should not be limited to their effects and relationships to human interactions. Thus, material studies of religion must proceed further and incorporate the elusive, enchanting modes of objects along with their religious materiality. Such steps will get us closer to comprehending the object-ness that slips away from the textures of signification but emerges in oscillations between desires, socio-religious imaginaries and material 
semiosis that operate across the realities of everyday lives. Speculative realism and OOO both offer an alternative for seeing the poetics rather than the politics of objects, in order to seek their tensile lives with regard to details and surpluses that configure materiality, object-ness, and becoming-an-object without reducing them to mere representations and the semiotic.

Webb Keane critiques evolutionary psychologists who suggest that religious ideas do not result from cultural tension and transition, stressing that whatever the religious notion or imaginary, "we must. .. [look] for those inferences that circulate socially and. .. enter into material forms" (2008: 230). The mystical practices of Isfahan's Khaksari murshid kuchak may well be romantic or unfounded to an outsider. However, the tensile and protean life of his tasbih teaches us how objects move alongside social, cultural, and religious inferences. The prayer beads move across realms of materiality via their objectness, semiotics, and signification, and tracing that movement exposes how they become a tasbih. Mullah Habib, murshid, Sufi, and craftsman, projected strong responses and attachments onto his own crafted tasbih. He despised mass-manufactured tasbihs, calling them plastic even when made of wooden beads, because he considered plastic, specifically Chinese-made plastic tasbihs, as soulless and void of aesthetics.

I share a concluding anecdote to highlight how material contributes to materiality. Mulla Habib was deeply offended by Chinese-manufactured tasbihs and religious products, and their presence prompted his usually calm demeanor to vanish. He refused to pray for or ask blessing for a woman who was handing a plastic tasbih to dervishes gathered for rituals around the mausoleum of Samsam. She intended to hand a hundred tasbihs to dervishes who commemorated Samsam in order to pray for her troubles, but Mulla Habib refused. This was a clear violation of the sanction of Majzoob Ali Shah, the qutb of the Gonabadi order, and Mir-Taher Alishah, the departed Shaykh-hozur of the Khaksari order who asked murshids and masters to not deny any request for prayers and blessings from the public and to remain generous with them. ${ }^{6}$ Mulla Habib refused the Chinese-made tasbih with the excuse that "they don't call me to themselves." However, I had often seen him get frustrated with plastic tasbihs because the beads would not slide over the strings as easily as wooden ones, or as his own clay tasbih. The holes in the Chinese-made beads were often tight or not suitably carved, making it hard to use them while trying to concentrate on prayers.

Chinese-made tasbihs may not hold prestige or perceived quality among Iranians and how they imagine craftsmanship and high-quality products. But to take Keane's idea a bit further, one could also suggest that Mulla Habib's relationship to the object is dependent on the way the object exposes its object-ness to him. It is about how the feel of the object and its ergonomics interact and interfere with religious practices. Mulla Habib's desire for his preferred tasbih was informed by his mystical interpretations, but the object-ness of tasbih contributed to his interpretations, too. To return to Harman (2011), his tasbih is neither representational nor made of invisible particles, but it is the

\footnotetext{
$\overline{5}$ Muhammad Samsam (1911-1980) was a renowned dervish who is buried in Isfahan. Dervishes of different orders gather around his mausoleum on different occasions to pray and chant. It is thought that if a person hands a hundred tasbihs to them to chant with, he or she can receive what is desired through their prayers. There are several unusual rituals attributed to this mausoleum, such as donating salt rather than sweets, which are customary in commemorating the dead.

${ }^{6}$ The Shaykh hozour is the head of a Sufi order, one step above murshid, while the qutb is the highest spiritual leader of the path that the order is associated with.
} 
object-ness that eludes his approach and yoyos between extremes of his articulation of the object. The story of the tasbih highlights not the religiously loaded object from the perspective of the faithful but rather how the "medium" shapes modes of mediation (Meyer 2011). The object-ness of objects shapes mediation by making the experience possible, memorable, and even pleasant. That pleasure would not be as vibrant if the raw materials did not project certain qualities such as an agreeable tactile connection, shine, lustre, and so on.

Open Access This article is distributed under the terms of the Creative Commons Attribution 4.0 International License (http://creativecommons.org/licenses/by/4.0/), which permits unrestricted use, distribution, and reproduction in any medium, provided you give appropriate credit to the original author(s) and the source, provide a link to the Creative Commons license, and indicate if changes were made.

\section{References}

Aamodt, A. M. (1983). Problems in doing nursing research: Developing a criteria for evaluating qualitative research. Western Journal of Nursing Research, 5(4), 398-402.

Barad, K. (2003). Posthumanist performativity: Toward an understanding of how matter comes to matter. Signs, 28, 801-831.

Brown, B. (2001). Thing theory. Critical Inquiry, 28(1), 1-22.

DeLanda, M. D. (2015). A new philosophy of society: Assemblage theory and social complexity. London: Bloomsbury.

DuBois, P. (2003). Slaves and other objects. Chicago: University of Chicago Press.

Edwards, T. B. (2004). The Kombolói Museum: Description or Prescription of a Traditional Greek Craft?. Folk Life, 43(1), 89-114.

Eisenlohr, P. P. (2009). What is a medium? The anthropology of media and the question of ethnic and religious pluralism. Utrecht: Universiteit Utrecht.

Garcia, T. (Ed.). (2014). Form and object (trans: Ohm, M.A. \& Cogburn, J.). Edinburgh: Edinburgh University Press.

Haraway, D. (1988). Situated knowledges: The science question in feminism and the privilege of partial perspective. Feminist Studies, 14(3), 575-599.

Harman, G. (2009). Dwelling with the fourfold. Space and Culture, 12(3), 292-302.

Harman, G. (2011). The quadruple object. Hants: Zero Books.

Harman, G. (2012). The Third Table/Der dritte Tisch: 100 Notes-100 thoughts/100 Notizen-100 Gedanken no. 85. dOCUMENTA (13). Kessel: Erschienen im Hatje Cantz.

Harman, G. (2013). Bells and whistles: More speculative realism. John Hunt Publishing: United Kingdom.

Harman, G. (2014a). Entanglement and relation: A response to Bruno Latour and Ian Hodder. New Literary History, 45(1), 37-49.

Harman, G. (2014b). Introduction. In T. Garcia (Ed.), Form and object (pp. 1-16). Edinburgh: Edinburgh University Press.

Hoskins, J. (2007). Afterword-Gendering religious objects: Placing them as agents in matrices of power. Material Religion, 3(1), 110-120.

Ingold, T. (2012). Toward ecology of materials. Annual Review of Anthropology, 41, 427-442.

Jones, A. M. (2003). From the perception of archaeology to the anthropology of perception: An interview with Tim Ingold. Journal of Social Archaeology, 3(1), 5-22.

Keane, W. (2008). On the materiality of religion. Material Religion, 4(2), 230-231.

Knysh, A. (2007). Epistle on Sufism: Al-risala Al-qushayriyya Fi "ilm Al-tasawwuf by Al-Qushayri, Abu "lQasim. Reading: Garnet.

Latour, B. (1983). Give me a laboratory and I will raise the world. Science observed, pp. 141-170.

Latour, B. (2005). Reassembling the social: An introduction to actor-network-theory. Oxford: Oxford University Press.

Law, J. (2009). Actor network theory and material semiotics. The New Blackwell Companion to Social Theory, 3, 141-158.

Meyer, B. (2008). Materializing religion. Material Religion, 4(2), 227.

Meyer, B. (2011). Medium. Material Religion, 7(1), 58-64. 
Meyer, B., Morgan, D., Paine, C., \& Plate, B. (2011). Introduction: Key words in material religion. Material Religion, 7(1), 4-8.

Morgan, D. (2008). The materiality of cultural construction. Material Religion, 4(2), 228-229.

Morgan, D. (2011). Thing. Material Religion, 7(1), 140-146.

Naguib, S. A. (2015). Materializing Islam and the imaginary of sacred space. Objects and Imagination: Perspectives on Materialization and Meaning, 3, 64.

Pinney, C. (2004). Photos of the gods: The printed image and political struggle in India. London: Reaktion Books.

Schiffer, B., \& Miller, A. R. (1999). The material life of human beings: Artifacts, behaviour and communication. London: Routledge. 